\title{
THE KABUPATÈN PROGRAM AND ADMINISTRATIVE REFORM
}

\author{
R. A. Richards
}

The Indonesian government has been directing considerable effort towards improving its public services as a means to achieving economic and social change. Various training programs, salary increases, and improvements in employee housing and office facilities reflect this trend. 1 Improvements in administrative performance are also apparent. For example, figures for yearly national revenues demonstrate clearly that the government's tax-collecting ability has improved. Revenue from non-oil sources increased from Rp. 179.3 billion in $1969 / 70$ to Rp. $1,146.7$ billion in $1976 / 77$, notwithstanding well-publicized "leaks" to collectors in the administrative processes.

What I am concerned with here, however, are improvements in how such funds are used. With the goal of improving public service performance, a number of major regional development programs designed for implementation at the local level have been put into operation during the last several years. At present there are at least seven of these Inpres (Instruksi Presiden) programs, ${ }^{2}$ which, in order of establishment, include the following:

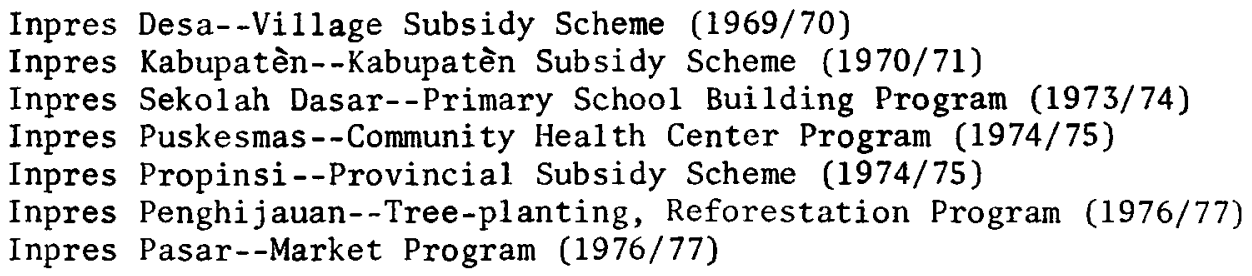

All together, some Rp. 277 billion is included in the $1977 / 78$ budget for these special regional and district development programs out of a total development budget of $\mathrm{Rp}$. 2,168 billion.

I have chosen to focus on the Kabupaten (District) Program, the stated objectives of which do not mention administrative performance, but in which major organizational and procedural changes, themselves defined most explicitly, were considered fundamental. This program is of particular interest as an example of what is widely regarded as a

${ }^{1}$ One may note in the national budgets, for example, that expenditures on personnel, including salaries and food supports, have risen from $\mathrm{Rp}$. 104 billion in $1969 / 70$ to Rp. 665 billion (Rp. $415=\$ 1.00$ ) in 1976/77, an increase of 540 percent; this increase is considerably greater than the 280 percent rise in the Jakarta Consumer Price Index for the same period. (Calculated from statement in Sinar Harapan, February 2, 1977.)

2One could also include the Candak Kulak (national scheme for small loans to villages, implemented in 1976) and a limited airfields program. 
successful government program, the administrative arrangements of which have served as a model for other major regional programs.

Kabupatèn Program Objectives

The original concept and early operation of the program have been well described elsewhere. ${ }^{3}$ Conceived primarily as an employmentgenerating program to improve the economic conditions of rural communities, its objectives are "to create and widen the field of employment through developmental projects in communication and production infrastructures, to promote distribution and transportation, to enlarge productive output, improve the living environment, increase the level of citizen participation, and to develop and support other projects within the district in the national development program."4 In somewhat greater detail, a tri-ministerial directive concerning the program stipulates that:

The projects are to be of moderate size, at the same time fulfilling the following conditions:

a) They will create a field of employment in their area of development, with the purpose of expanding work opportunities;

b) They will make use of locally available manpower and materials and use as few imported commodities as possible;

c) Within a short time they will help to increase agricultural production and promote distribution and transportation of agricultural produce, at the same time improving the living conditions of members of the society with low incomes;

d) They will increase popular participation in development;

e) They are technically justifiable;

f) Construction work on the projects will be carried out by genuine wage payment and not by [unpaid] cooperative work;

g) Staff and technical experts available within the kabupatèn must be capable of planning, supervising, and completing the projects;

h) The execution of a project may not depend on other projects;

i) They can be completed in one financial year;

j) They are projects the priorities of which are in harmony with projects of the district, of the province, and developmental projects at the national leve 1.5

In additional notes to the tri-ministerial instruction, the Minister of the Interior specifies each year the kinds of projects permitted in the program, which now include: "Roads, irrigation channels, reservoir floodgates, tree replanting and reforestation, terracing for rice cultivation, flood prevention, village infrastructure improvement, drainage, vegetable and cattle markets, bus stations. Projects for the maintenance of roads, bridges and associated drainage, dikes, dams, reservoirs, and all kinds of irrigation construction." Projects not

"See Y. B. de Wit, "The Kabupaten Program," Bulletin of Indonesian Economic Studies, 9, 1 (1973), pp. 65-85.

4 Instruksi Presiden R. I. Minute No. 6 Tahun 1976 tentang Program Bantuan Pembangunan Daerah Tingkat II, Pasal 1 (i).

${ }^{5}$ Keputusan Bersama Menteri Dalom Negeri, Menteri Keuangan, Menteri EKUIN/Ketua Bappenas tentang penetapan jumlah dan pedoman pelaksanaan Program Bantuan Pembangunan Daerah Tingkat II Tahun 1976/77, Pasal 2. 
permitted are: "Buying office equipment and furniture; 1 and development projects which have no economic function for development, such as office buildings, houses, swimming pools, etc.; providing working capital either for the government of the district itself or for other parties in the community."6 The Minister notes that proposals from subdistrict officers (camat) should be given due attention and that project priorities should be based on district needs.

\section{Program Finance}

Following a pattern established in 1969 in a nationwide village subsidy program, and departing from what was then established practice, the program was funded through the national budget with allocations made directly to individual kabupatèn (kotamadya in the case of cities). The amount allocated was originally calculated on the basis of Rp. 50 per person, with a minimum payment of $\mathrm{Rp} .5$ million per kabupatèn. This grant has increased gradually and in the $1977 / 78$ budget will be $\mathrm{Rp} .450$ per person, with a minimum of $\mathrm{Rp} .40$ million. In addition, since $1972 / 73$ the kabupatèn are being provided with power road-rollers; since $1973 / 74$, provincial supervisory staff have been paid extra for their involvement in the program; and in $1975 / 76$ each province was given a four-wheeled vehicle. Since 1972/73, additional payments have been made dependent on satisfactory attainment of land tax (Ipeda, Iuran Pembangunan Daerah) targets. Expenditures in recent years are shown in Table 1 .

TABLE 1

FUNDS PROVIDED FOR KABUPATÈN PROGRAMS

(Rp. Million)

\begin{tabular}{lrrrrr}
\hline \hline & $1972 / 73$ & $1973 / 74$ & $1974 / 75$ & $1975 / 76$ & $\begin{array}{r}1976 / 77 \\
\text { (est.) }\end{array}$ \\
\hline Aid & 12,162 & 18,008 & 37,900 & 52,995 & 55,728 \\
Ipeda Incentive & 338 & 742 & 3,295 & 3,173 & 2,891 \\
Road-Rollers & 300 & 250 & 1,205 & 2,892 & 2,892 \\
Provincial Involvement & - & 200 & 100 & 175 & 200 \\
Provincial Vehicles & - & - & - & 104 & - \\
Toral & 12,800 & 19,200 & 42,500 & 59,072 & 62,400 \\
Minimum per Kabupatèn & 10 & 12 & 16 & 20 & 30 \\
\hline
\end{tabular}

Source: Laporan Pelaksanaan Program Bantuan Pembangunan Daerah Tingkat II Tahun 1975/76 dan Reneana Tahun 1976/77 (Jakarta: Dirjen. Pemerintahan Umum Dan Otonomi Daerah, Departemen Dalam Negeri, 1976).

Each year, limits have been placed on the maximum amount to be spent on any single project. The $1974 / 75$ limit of Rp. 25 million was raised to $\mathrm{Rp}$. 50 million in 1975/76. Projects involving expenditures greater than the maximum must be submitted to the Minister of the Interior for approval.

'Himpunan Peraturan Sebagai Pedoman Pelaksanaan Program Bantuan Pembangunan Daerah Tingkat II Tahun 1975/76 (Jakarta: Dirjen. Pemerintahan Umum dan Otonomi Daerah, Departemen Dalam Negeri, 1976). 


\section{Administrative Procedures}

The annual operating cycle of the Kabupatèn Program is geared to the timing of the national budget. The process begins in October, when each district head (bupati) prepares a list of priority projects for submission to the provincial governor. The 1 ists are then processed at the district, provincial, and national levels in time for the selected projects to be included in the budget of the financial year that will begin the following April. The implementation of each project is usually negotiated between the bupati, as project leader, and a private contractor, although the work may be undertaken directly by kabupatèn technical staff. In detail:

1. The bupati prepares a list of priority projects which, after presentation to the district legislative council, is submitted to the governor.

2. In the provincial office, this list is checked to make sure it fits technically and financially with other projects.

3 . The list is approved by the governor and returned to the kabupatèn .

4. In the kabupatèn, the proposed projects are studied by kabupatèn technical officers. This study involves:

a) Making any necessary measurements at the location of the proposed project;

b) Carrying out any investigation necessary for constructing earthworks, foundations, etc., e.g., drilling and sounding;

c) Other research into sources of materials, e.g., local stone and gravel;

d) Preparation of design drawings;

e) Analysis of planned expenditures, contractors' profits, expenditures on project direction, etc.

The kinds of project expenditures consist of:

a) Preparation expenditures;

b) Construction expenditures (including taxes);

c) General expenditures for project leadership, project treasurer, technical staff, field supervision, administrative staff, any other officials. The appointment of these officials must be confirmed in writing by the bupati. The monthly honorarium for each official for the period of the project may not exceed 50 percent of his basic monthly salary;

d) Expenditures on travel to the provincial offices for committee meetings, or to the project for supervision;

e) Administrative payments, including purchase of writing materials, preparation of papers and photos for the project, and meal expenses for meetings.

5. Summaries of expenditures for each kind of project, the projects themselves, the kinds of monthly expenditures, and a schedule of daily wages and prices of the required building materials are then transmitted to the governor together with the proposal for each project (Daftar Urusan Rencana Proyek, or DURP) and a location map.

6. The governor checks the DURP and attachments, together with a schedule of planned general expenditures and the preliminary 
budget for the following financial year. He is required to have the support of the provincial departments of public works, manpower, agriculture, and other bodies with special interests in the projects; the regional planning body (Bappeda, Badan Perencanaan dan Pembangunan Daerah) also participates in approval of projects.

7. In March, two officials from the provincial supervisory team bring the DURP, reports, and summaries to Jakarta for consul tation with the national supervisory team, which includes officials from the departments of public works, manpower, agriculture, finance, interior, and the national planning board.

8. The approved project proposals are returned to the province and formally approved by the governor.

9. The governor then returns them to the bupati for action.7

The bupati, as the formal project leader, nominates a project treasurer, who must be approved by the governor; the bupati himself appoints other project officials. Financial and technical supervision and control procedures are spelled out in detail by the Department of the Interior. The Minister of Finance authorizes project expenditures as stipulated in the DURP; authorization and funding are made through the Bank Rakyat Indonesia. ${ }^{8}$ Contractors are selected by a kabupatèn committee composed of the bupati and heads of relevant departments, again following national government procedures.

Payments are made as work progresses by the local branch of the bank. The project treasurer presents contractors' accounts and reports of physical progress (berita acara) certified as correct by authorized kabupatèn technical staff, and the contractor is paid by check. Where work is done by kabupatèn employees, the project director provides the project treasurer with a detailed payment plan, and the treasurer then submits requests for payment to the bank to obtain the necessary cash. The bank extracts taxes from each payment.

For both the financial and technical aspects of a project, a set of administrative reporting/supervision systems is required within the kabupatèn. The project leader and the treasurer must send monthly reports to the governor. The governor in turn reports monthly to the Department of the Interior, the Department of Finance, and the National Planning Board. Photographs of the project site and work in progress must be sent to Jakarta before the work begins, at mid-stage, and on project completion. The Minister of the Interior reports to the Minister for the Direction of the National Development Program and to the President. At the same time, a parallel reporting system in the bank advises the bank head office and the three ministries of their financial records on the projects.

\section{Evaluation}

The program must be evaluated in terms of its original objectives, both declared and implicit. The former are set out in the initial presidential instructions and have been repeated each year. They include:

7Ibid. $\quad{ }^{8}$ For Irian Jaya, the Bank Export/Import. 
1. Development projects in communication and production infrastructure, to provide

2. Enhanced employment prospects, and an

3. Increase in the level of citizen participation in development activities.

4. Projects should develop and support other projects in provincial and national programs.

Improvements in the administrative apparatus are indispensable to the attainment of the declared objectives. The ministerial directives detailing the conditions under which these objectives are to be achieved illustrate this clearly. The procedures deliberately and substantially constrain the activities of district-and provincial-level officials. There is general agreement that administrative change is an integral part of the scheme, directed specifically towards improving the performance of district officials in manaing their local public works programs. ${ }^{9}$

In designing the administrative procedures, attention was also given to the problem of corruption. According to De Wit, "It was logical that, under Indonesian circumstances, minimizing corruption should be put forward as a separate basic principle of the program."10 Corruption was deliberately attacked through a set of multiple checks, first by collegiate selection of contractors, then by insisting on certified progress reports involving technical personnel, and finally in payment by check by the Bank Rakyat Indonesia directly to the contractor. The provision for payments (in addition to normal salary) to those taking part in the administration of the program was also designed to reduce incentives to illegal diversion of funds; substantial incentive payments are made to administrative and technical personnel at the kabupatèn leve1.

Physical Realization

Physical achievements are reported annually and are given in Table 2. The data are impressive, especially if one compares, for example, the length of kabupatèn roads rehabilitated or constructed with the total length of kabupatèn roads. Roads are classified into national roads, provincial or secondary roads, district (kabupatèn) roads, and small roads and tracks into villages. Estimates vary as to the length of kabupatèn roads, but I have taken for comparison a semiofficial figure of $52,000 \mathrm{~km} .{ }^{11}$ The figure of $34,707 \mathrm{~km}$ of roads worked on under the kabupatèn program should thus mean that a substantial impact has been made on road communication between small towns and between these towns and the villages they service. Most program expenditures so far have been for roads, bridges, and irrigation channel improvement.

9Noted by De Wit, "The Kabupaten Program." The relevance of the program for improvement in the administrative apparatus was noted in interviews with Atar Siberu (Dept. Dalam Negeri), January 31, 1977, and with T. A. Salim (Bappenas), February 17, 1977.

${ }^{10}$ De Wit, "The Kabupaten Program," p. 73.

${ }^{11} \mathrm{~A}$. Madjid Ibrahim, "Infrastructure for Regional Development," Indonesia Magazine, 32 (1975), p. 57. For another estimate $(40,000 \mathrm{~km})$, see Kompas, December 11 , $1976, \mathrm{p} .12$. 
TABLE 2

KABUPATÈN PROGRAM: PHYSICAL REALIZATION

\begin{tabular}{|c|c|c|c|c|c|c|c|c|c|c|}
\hline & & $1970 / 71$ & $1971 / 72$ & $1972 / 73$ & $1973 / 74$ & $1974 / 75$ & $1975 / 76$ & $1976 / 77$ & Total & $\begin{array}{l}\text { Number of } \\
\text { Projects }\end{array}$ \\
\hline Roads & $\mathrm{Km}$ & 3,016 & 3,748 & 4,408 & 5,030 & 6,848 & 5,970 & 6,687 & 34,707 & 8,425 \\
\hline Bridges & M & 12,259 & 15,330 & 18,754 & 20,920 & 22,037 & 18,285 & 17,712 & 135,277 & 4,848 \\
\hline $\begin{array}{l}\text { Irrigation } \\
\text { Dams } \\
\text { Channels } \\
\text { Structures } \\
\text { Area served }\end{array}$ & $\begin{array}{l}\mathrm{M}^{3} \\
\mathrm{Km}\end{array}$ & $\begin{array}{r}238,803 \\
507 \\
124 \\
57,808\end{array}$ & $\begin{array}{r}479,741 \\
229 \\
163 \\
114,828\end{array}$ & $\begin{array}{r}356,218 \\
332 \\
281 \\
87,126\end{array}$ & $\begin{array}{r}447,723 \\
568 \\
790 \\
124,376\end{array}$ & $\begin{array}{r}207,581 \\
668 \\
1,164 \\
128,243\end{array}$ & $\begin{array}{r}249,205 \\
1,190 \\
2,638 \\
138,377\end{array}$ & $\begin{array}{r}237,783 \\
776 \\
1,188 \\
111,395\end{array}$ & $\begin{array}{r}2,217,056 \\
4,289 \\
6,348 \\
762,153\end{array}$ & $\begin{array}{c}1,619 \\
1,238 \\
856 \\
-\end{array}$ \\
\hline Markets & $M^{2}$ & 87,266 & 106,343 & 274,052 & 50,090 & 128,861 & 137,721 & 387,617 & $1,171,980$ & 810 \\
\hline Drainage & M & 21,849 & 42,362 & 86,732 & 83,353 & 121,160 & 254,069 & 306,020 & 863,696 & 580 \\
\hline Reforestation & $\mathrm{Ha}$ & 4,095 & 2,581 & 7,134 & 164,264 & 32,200 & 22,643 & 10,774 & 243,531 & 346 \\
\hline Flood Prevention & $\mathrm{Ha}$ & 2,980 & 2,716 & 6,071 & 9,503 & 20,695 & 14,838 & 15,778 & 72,503 & 182 \\
\hline Bus Stations & & 15 & 36 & 27 & 17 & 8 & 62 & 32 & 197 & 207 \\
\hline River Wharves & & 9 & 13 & 14 & 28 & 19 & 21 & 31 & 135 & 135 \\
\hline Culverts & M & 441 & 632 & 2,555 & 2,113 & - & 3,875 & 3,666 & 13,282 & 1,137 \\
\hline Other Projects & & 105 & 145 & 136 & 636 & 3,998 & 1,369 & 986 & 8,175 & 826 \\
\hline Number of Projects & & 1,791 & 2,393 & 2,833 & 2,863 & 4,072 & 3,861 & 3,443 & - & 21,255 \\
\hline $\begin{array}{l}\text { Amount of aid } \\
\text { Rp. } 000,000\end{array}$ & & 5,700 & 8,823 & 12,866 & 19,208 & 42,500 & 59,072 & 62,400 & 210,569 & - \\
\hline
\end{tabular}

Source: Beberapa Catatan dan Tata Cara Pelaksanaan serta Data Data Program Bantuan Pembangunan (Inpres), Tahun 1970/71-1976/77 (Jakarta: Dirjen. Pemerintahan Umum dan Otonomi Daerah, Departemen Dalam Negeri, 1976). 
A few studies undertaken in a small sampling of kabupatèn have shown that Inpres projects have had an impact at the local level. For example, in a study made in South Sulawesi by research personnel from the Institute for Economic and Social Research at the Universitas Hasanuddin, a substantial majority of respondents believed that incomes of local residents had been increased because of the 1,103 projects completed there between 1970/71 and 1975/76.12 In Jogjakarta, Gadjah Mada University's Economics Research Institute found that a majority of the respondents to their survey knew of the aims and uses of projects and agreed with the choice of projects.13

\section{Employment Effects}

The employment absorption effects of the program are usually expressed in terms of manpower absorbed in units of 100 man-days, as follows:

TABLE 3

KABUPATÈN PROGRAM: MANPOWER ABSORBED IN 100 MAN-DAYS

$\begin{array}{rrcr}1970 / 71 & 210,568 & 1974 / 75 & 905,130 \\ 1971 / 72 & 302,758 & 1975 / 76 & 1,017,131 \\ 1972 / 73 & 436,612 & 1976 / 77 & 824,398 \\ 1973 / 74 & 533,737 & \text { (est.) } & \end{array}$

Source: Beberapa Catatan dan Tata Cara PeZaksanaan serta Data Data Program Bantuan Pembangunan (Inpres), Tahun 1970/71-1976/77 (Jakarta: Dirjen. Pemerintahan Umum dan Otonomi Daerah, Departemen Dalam Negeri, 1976).

The many official statements concerning the results of the Kabupatèn Program are based on these figures. However, it should be noted that they are assembled from the original estimates in the individual project proposals, not from reports on work actually completed. There are numerous reasons to doubt their validity, including:

1. Corruption. This is the most obvious source of error. It is widely believed that funds available to develop the kabupatèn-leve 1 infrastructure are not fully devoted to this work, but are partly diverted to benefit officials involved in the program. The extent of this corruption is commonly estimated at up to one-third of the total funds, 14 though of course it is difficult to find concrete confirmation of this. Those quoting this percentage may not be aware of the extent to which legal incentive payments are provided to administrative and technical staffs. There are funds for honoraria, attendance money, and

${ }^{12}$ Laporan Penelitian Program Kabupaten dan Pengaruhnya Terhadap Kesempatan Kerja serta Income di Sulowesi Selatan (Ujung Pandang: Universitas Hasanuddin, February-Apri1, 1976).

${ }^{13}$ Noegroho and Wahibsujitno, Evaluasi Pelaksanaan Program Bantuan Pembangunan Daerah Tingkat II di Daerah Istimewa Yogyakarta (Jogjakarta: Lembaga Penelitian Ekonomi, Fakultas Ekonomi, Universitas Gadjah Mada, 1976), pp. 49-50.

${ }^{14}$ Estimates of corruption at this level have also been noted by $\mathrm{R}$. Wm. Liddle, "Indonesia 1976: Challenges to Suharto's Authority," Asian Sumey, 17, 2 (February 1977), p. 99. 
traveling expenses; up to 5 percent of the overall program funds are allowed for plan preparation, supervision, and control activities, 15 and this can rise to 10 percent for large, complex projects. (The average project size is in fact becoming larger year by year.) ${ }^{16}$ Such incentive payments are excluded from the calculation of the employment effects of the program. Yet it is still widely believed that substantial illegal payments are made by contractors to officials responsible for negotiating contracts and that illegal payments are expected by officials involved in the administration of the program. One newspaper comment, which may be indicative, alleges that "payments between contractors and those who award contracts, especialiy in government circles, still continue. A contractor for government projects spoke of these [payments] as compulsory, because if they are not made it is difficult to obtain one's objectives." According to this report, bribes are used to obtain information on tender prices, inside information on the funds available for the project, and calculations for inclusion in the tender, all with the certain knowledge of the project leadership. (A less refined method is to submit tenders from at least five businesses owned either by the contractor or his friends.) If the contractor is successful, he needs to make additional nonofficial payments to the project leaders and staff and still more payments to facilitate the issue of money. "The total of such payments, at a minimum, comprises 10 percent of the project price, so if he hopes to get only a 15 percent profit, what with interest and other payments, the contractor will incur a loss. To make up this loss, the contractor is forced to play around so that the quality of work is far below specification."17

The amounts involved in miscellaneous extraneous payments range from $\mathrm{Rp} .1,000$ to obtain contract papers to $\mathrm{Rp}$. 25,000 for district coordinating officers. In all, fourteen separate types of payment are specified, "and also many other outlays difficult to detail. These payments are usually made by each contractor every time he receives a payment."18 An estimated Rp. 300,000-400,000 could be involved in any one contract, which would represent some 2 percent of the total average project budget of Rp. 17 million. In view of such substantial illegal payments, the amount of money available for labor and materials is considerably less than official estimates, and it would appear that the real labor absorption effect of the program is also correspondingly lower.

2. Labor Intensity. The figures in Table 3 include not only man-days worked on projects but also an estimate of employment generated in the district or districts near the project location through the preparation and supply of materials. An estimate of the employment

${ }^{15}$ Laporan Pelaksanaan Program Bantuan Pembangunan Daerah Tingkat II Tahun 1975/76 dan Rencana Tahun 1976/77 (Jakarta: Dirjen. Pemerintahan Umum dan Otonomi Daerah, Departemen Dalam Negeri, 1976).

${ }^{16}$ Interview with $T$. A. Salim.

17Kedaulatan Rakyat (Jogjakarta), February 8, 1977. This article states that other contractors who usually work on government contracts have the same experiences. Reports from contractors and other sources in Jakarta indicate bribe levels ranging from 10 to 15 percent of the contract price.

${ }^{18}$ Kompas, December 9, 1976. 
man-days, both in actual work on the project and in obtaining materials from local sources (stone, sand, bricks, etc.), is included on every DURP. The estimate is calculated as follows:

$$
\begin{aligned}
& \text { Average Wage }=\frac{\text { Wage of } 3 \text { unskilled workers }+ \text { Wage of } 1 \text { skilled worker }}{4} \\
& \text { Number of man-days }=\frac{\text { Wages bill }+80 \% \text { of cost of local materials }}{\text { Average Wage }}
\end{aligned}
$$

It is assumed that the wages for labor in processing local materials are about 80 percent of the price paid for the material. This is a reasonable procedure for estimating the employment-generating effects of the scheme, although it could give the mistaken impression that the "manpower absorbed" figures represent direct employment on the projects themselves. The actual breakdown of expenditures is illustrated in the 1975/76 Kabupatèn Program annual report:

\section{TABLE 4}

USE OF FUNDS: KABUPATENN PROGRAM 1975/76

$\begin{array}{lr}\text { Wages } & 25.69 \% \\ \text { Local Materials } & \\ \text { (Stone, sand, bricks, timber, tiles) } & 39.64 \% \\ \text { Other Materials } & 25.49 \% \\ \text { Tools } & 1.32 \% \\ \text { Land Compensation } & 1.23 \% \\ \text { Miscellaneous } & 6.65 \%\end{array}$

Source: Laporan Pelaksanaan Program Bantuan untuk Pembangunan Kabupaten dan Kotamadya. Tahun 1975/76 dan Rencana untuk Tahun 1976/77 (Jakarta: Dirjen. Pemerintahan Umum dan Otonomi Daerah, Departemen Dalam Negeri, 1976).

These data show the importance of the labor content of local materials --31.71 percent (i.e., 80 percent of 39.64 percent), a figure which is still greater than the onsite wages content of the program. The "labor content" of the program for $1975 / 76$ would have been the sum of wages (25.69 percent) plus labor in materials ( 31.71 percent), or 57.40 percent. A labor-capital ratio of $60: 40$ is cited in Jakarta circles as the original assessment of the program's impact. Senior personnel associated with the scheme now believe the labor content to be less than this and consider it closer to 50:50.19 Such a revised ratio would reduce the estimated manpower absorption effect to 16.7 percent.

3. Spread of Employment. The presentation of the data in Table 3 in terms of a timespan of 100 man-days reflects the original plan, in which projects would largely be carried out during the dry season, when there is little agricultural work available, and thus provide a source of added income during a slack period. Whether this expectation reflects the actual situation or not is questionable. Independent studies of the program's effects on local employment show that contractors do not feel bound to hire labor available at the project site. They often prefer to bring in their own employees, saying that local 
people lack the necessary discipline. This attitude applies particularly to more skilled labor, but to unskilled labor as well. One report showed that there was a project where no one was employed from the village where the project was located.20 An earlier report from West Java found that the percentage of employees from the village in question and neighboring villages was 23 percent for one project and 43 percent for another.21 Another report concludes, "Quantitatively - . the influence of these Inpres projects is stili felt to be very small when judged in terms of work opportunity."2z The notion that the projects should provide work for local people has not been put into practice consistent1y.

The impact of these three factors on kabupatèn program employment is uncertain but can be hypothesized by considering their combined effect on the original concept. In theory, an amount of $P$ (project contract price) is available for the job, to be shared between labor and capital in the ratio $60: 40$ so that the share to 1 abor is $0.60 P$, intended to give employment for about three months to each person employed either directly in the project or in supplying it. In practice, at least 10 percent of the contract price $P$ is drained away in illegal payments, leaving $0.90 \mathrm{P}$ for distribution to capital and labor; if this amount is distributed equally, the amount available for employment thus becomes $0.45 \mathrm{P}$. What is the impact of this percentage on local employment? For direct onsite employment, figures have been quoted of from zero to 43 percent local employment. There are no data on the local labor factor in the "supply" sector of project maintenance. I would conservatively suggest that not more than 50 percent of 1 abor funds are used to hire casual labor, while the balance is used to pay people employed on a more regular basis by contractors and material suppliers.23 Accordingly, of the amount $0.45 P$ available for employment,

$0.225 P$ can be regarded as generating employment for three months a year, and

$0.225 P$ can be regarded as providing employment for people who work on a more regular basis, that is, for something approaching fulltime employment, which might be considered as nine months per year. This would provide employment for only one-third of the number of people determined by the formula, and the total employment generating effect of the $0.45 P$ would be, in terms of the concept underlying the formula, $(0.225+0.075) P=$ $0.30 P$.

2openelitian Socio-Agro-Ekonomi Daerah Tuntang Serang di Wilayah Kabupaten Demak Grobogan dan Lima Desa Scompel (Salatiga: Lembaga Penelitian Ilmu-Ilmu Sosial, Universitas Kristen Satya Wacana, 1975), ch. 1.

21Pengaruh Proyek Inpres Tahun 1970/1 dan 1971/2 terhadap Kegiatan Ekonomi dan Kesempatan Kerja (Bandung: Biro Penelitian Ekonomi dan Masyarakat, Fakultas Ekonomi, Universitas Pajajaran, 1972) .

22Noegroho and Wahibsujitno, Evaluasi Pelaksanaan, p. 56.

${ }^{23}$ The 50:50 ratio is, of course, an estimate, as are the other ratios in this calculation; but I believe that all of them err on the side of overstating the "employment-generating" effect of the program. 
This means that instead of a given number of people being employed for three months on the basis of $0.60 P$, only half this number are really working, some, of course, for a longer period. An official estimate of $1,000,000$ employed in a particular year thus needs to be reduced to some 500,000 .

\section{Community Participation}

The stated objectives of the Kabupatèn Program give priority to community participation, but participation by community political representatives was explicitly excluded: "No place was made in the scheme for local political representatives and the possibility of factionalism."24 The initial prohibition on participation by elected representatives has been relaxed slightly, and the district legislative council is now allowed a minor role in longer-term planning. For the budget year $1975 / 76$, the legislative council leadership participated in the preparation of project plans for 1976/77--the council was given the priority 1 ist before the bupati sent it on to the governor. Since 1975/76, the program funds have been included in the kabupatèn's annual budget, and some discussion is possible during the meeting at which the bupati presents the budget. However, this is nothing but a formality. With Golkar majorities in the councils there is likely to be little conflict of views. In effect, according to a senior official of the Department of the Interior, most political comment on the program comes from representatives in the national legislative assembly. Lower-echelon political officials are formally involved in some other Inpres programs, e.g., those for primary schools, community centers, and reforestation, but not in the public works program. One we11-placed observer notes that although "the program had not been subject to popular control, far less participation.. . Lurahs have been largely instrumental together with Camats in determining local priorities."25

However, politicking in the selection of projects still exists. Given the small number of projects in each kabupatèn (on an average of six in 1971/72, twelve in 1976/77, for a district with about half a million inhabitants), competition among the advocates of various projects must be keen, at least initially. To the extent that program funds have been spent in rehabilitating existing structures, some established community priorities have obviously received attention. There is, however, some evidence (in local surveys and other local comment, and in the press) that projects have not always been to best community advantage. This question of community satisfaction merges with the wider issues of regional and national interest.

\section{To Support and Develop Other Projects}

National unity and overall rationality in spending public funds are the final major objectives of the Kabupatèn Program. Here, the program becomes part of an overall administrative movement to modernize

\footnotetext{
${ }^{24} \mathrm{~K}$. A. Pickering, "The Kabupaten Program," mimeographed (Birmingham: Institute of Local Government Studies, University of Birmingham, 1974), p. 3.

${ }^{25}$ Ibid., pp. 7-8.
} 
systems and procedures and to improve the skills of personne1, especially in planning, and to a lesser extent, control. It is of a piece with other programs for administrative improvement, especially those in regional planning. The cooperation of many groups, offices, and departments is needed in order for the program to function effectively. Lately, regional planning personnel have been formally involved in the process; they are required to participate both in long-term planning and in the annual review of project priorities.

\section{Work Qua1ity}

Roads, bridges, and canals can easily be built, given sufficient funds, but for the program to be judged adequate, these structures must be well-built. Public works construction is in the main carried out by private contractors, the primary responsibility of the public service being to ensure good design and completion of the work. According to some reports, the latter, at least, is lacking. Some contractors admit as much, and a number of observers with whom I spoke noted the poor quality of the work; comments to this effect appear in the news media from time to time. In the South Sulawesi report, reference is made to "thin asphalt, undulating road surfaces, and gutters altogether wrong."26 Local residents enjoy the benefits of the projects but comment on the poor work, attributing it to poor supervision. Tools are also of poor quality. These features are, of course, not visible in the photographs required in the reports. Juxtaposed against these local observations is the belief expressed by national-level observers who inspect projects that the quality of work is improving each year. However, inadequate project supervision has been noticed, and falsification of technical progress reports has 1 ed to questions being raised about the program in the national legislature. In 1974, a team from the World Bank noted the need for improved technical competence and suggested a substantial training program to improve local skills. The suggestion was not acted on at the time, but attempts are now being made to involve provincial public works engineers more directly in kabupatèn works activities.

Improving technical competence does not of itself solve the problem of work quality, especially when the kickbacks system involves the technical staff. If the engineering inspector insists on adequate performance, the contractor can suffer financially and would be less likely to cooperate in the future, and the entire system would collapse. But the prospect of such massive social change is dim, and the problem of independent audit still remains. The designers of the program deliberately attacked corruption through a set of multiple checks, first by a collegiate selection of contractors, then by insisting on certified progress reports involving other personne1, and finally by checks through the bank. But although these procedures may have diminished the magnitude of corruption, they have not solved the problem. Audits through detailed inspection by independent teams from the public works head office in Jakarta have been contemplated but are currently ruled out because of the magnitude of the program $(3,400$ projects per year). Instead, greater involvement of provincial-level personnel is currently the focus of attention; ${ }^{27}$ heretofore, provincial public works staff

${ }^{26}$ Laporan Penelitian, ch. 1. $\quad{ }^{27}$ Interview with T. A. Salim. 
have pleaded lack of time. Whether they can be truly independent is an open question.

However, the question of quality is probably even more important. If illegal payments were abolished completely, an additional 10 percent or so of funds would be available for local public works. But if roads designed to 1 ast four years 1 ast only three, the government will be faced with an additional burden of 33 percent of the roads component of the program. Since $1974 / 75$, some 20 percent of 1 and tax fees must be reserved for maintaining Inpres structures, but, needless to say, this cannot correct earlier mistakes.

\section{The Kabupatèn Program and Administrative Change}

Inpres programs have become an established part of the Indonesian bureaucracy, in large part because of the perceived success of the kabupatèn public works program. In the original model and subsequent modifications, procedures have been instituted to improve skills and change attitudes of public servants at all levels. Some observers have seen the program as an exercise in decentralization, in that for the first time significant results have been achieved in a kabupatènlevel government program under the New Order. However, the kabupatèn public works program is clearly characterized by a high degree of centralized control. The statement in the Provisional Constitution of 1950 (Art. 131:2), that each district would be given the greatest possible degree of autonomy for the management of its local affairs, was reinforced in the Basic Law No. 1 of 1957, which was still the law when the Kabupatèn Program was introduced in 1969. But in fact, of course, centralizing tendencies have prevailed during both Guided Democracy and the New Order. Yet any notion of public servants as a monolithic corps enforcing directives from the central government ignores the reality of local sentiment, poor communications, and the weak financial position of district governments. Particularly during the 1960s, district governments became increasingly impoverished. They did their best with whatever funds they could get from unofficial as well as official sources. This was the situation faced by the drafters of the Kabupatèn Program. If the earlier administrative pattern had been maintained--and this was the thrust of political pressures early in the New Order--funds from the central government for local public works would have been made available completely under the direction of local governments. This would have been real decentralization and would have fulfilled widespread expectations among district administrators. Instead, as we have seen, strongly centralized administrative procedures were instituted. From the outset, the plan has been a national one, funded from the national budget and channeled through a national bank. Presidential and ministerial instructions from the center set out procedures in detail. Individual proposals for thousands of projects are brought by provincial officials to Jakarta for final inspection. Supposediy this occurs on a sampled basis, but it is easy to see how kabupatèn officials might come to view the entire system as undermining their autonomy, since they had once been accustomed to much greater independence.

Under the new system, strong emphasis has been placed on improving "organizational rationality." The role of planning has been strengthened in both financial and technical areas. Annual budgets are used 
for planning and control, and system designers are pleased with the bupati's increasing ability to use funds with a sense of timing oriented toward project completion.

\section{Evaluation}

There are two questions involved in evaluating changes in administrative procedures: (1) Are the new procedures being followed, and (2) are the objectives of the new procedures being realized? As far as the kabupatèn program is concerned, some bupati were initially unwilling to submit to the discipline of procedures imposed from above, and active personal supervision by high-level departmental officials was necessary to ensure the viability of the plan; some officials, it is said, were even brought to Jakarta for personal persuasive interviews by the Minister of the Interior himself. Even today, such highlevel personal intervention is by no means uncommon.

Procedural shortcomings are noted in annual reports. In the latest report available $(1975 / 76)$, examples of work not in accordance with regulations are 1 isted. These include:

2.7.1 A large proportion of the project leaders do not inspect the project treasury to carry out the Cash Inspection Progress Report.

2.7.2 A large proportion of the project leaders are still buying materials and selecting contractors involving amounts more than Rp. 500,000 without tenders.

2.7.3 A large proportion of the project leaders are still paying for materials and services involving more than $\mathrm{Rp} .2,000,000$ without using checks.

2.7.4 There still is payment for projects where the progress reports are not correct.

2.7.5 Funds are used for general and miscellaneous expenses not specified in the regulations.

2.7.6 DURP have not been properly approved by the governor.

2.7.7 Physical realization of the projects is not in accordance with DURP .

2.7.8 Projects are not in accordance with their declared objectives.

2.7.9 The districts are not sending monthly reports and photographs.

Action has already been taken on these shortcomings.28 A general satisfaction with adherence to procedures was expressed to the writer by senior personne1 in the Department of the Interior and on the National Planning Board.

The procedural objectives of the Kabupatèn Program include:

1. Responsible use of public funds with the public welfare as the primary goal, resulting in

${ }^{28}$ Laporan PeZaksanaan, para. 2.7. 
2. The provision of adequate physical structures, through

3. Improved rationality in the evaluation of community needs and in the selection of projects,

4. Improved relationships among specialist groups, and

5. The development of suitable attitudes as a basis for improved administration in preparation for greater local autonomy in the control of the program.

We have al ready noted some progress toward these objectives. Clearly point (5) has not yet been attained. But some relaxation has been allowed in the frequency of reporting, and there are plans to shift more responsibility for overall planning and for financial and technical supervision to the provincial level. Point (4) will always be something of a problem, given bureaucratic habits, but at least the procedures exist for bringing specialists together in a common forum. For point (3), the procedures, especially the DURP, deliberately draw attention to organizationally relevant aspects of the planning and control of public works, and there has been marked improvement in the kabupatèn contribution to the assembly and presentation of material. The main difficulty regarding point (2) is that of providing adequate supervision and control of work quality by people willing and able to take corrective action where necessary. Training is underway to prepare provincial personnel for more involvement in supervision and control. A training program to improve the research and evaluation capabilities of provincial staff will extend to eight provinces in 1977 and later to all provinces. At the same time, provincial public works engineers will be provided with adequate staffing and incentives to attract their full involvement.29 This activity will hopefully 1 ead to some improvement in point (1), the actual results in the eyes of the community. Yet substantial improvement will only take place when illegal procedures are eliminated.

In official commentaries, much is made of the idea that a major source of contribution to development has at last been discovered, i.e., widespread participation by workers throughout the nation. What was in fact missing before the Kabupatèn Program was initiated was money, and given this ingredient almost any administrative apparatus can achieve results. From an administrative viewpoint, the problem was to organize a system to get the best results for the money available. The designers of the Kabupatèn Program had to deal with regional and district administrators who had long experienced personal freedom in running their local affairs, and for whom the existing legal framework provided a fair degree of autonomy in dealing with local matters such as smal1-scale public works. To strengthen the role of 1 ocal administrators in making decisions on project location, the designers of this local public works program opted to suspend the input of local representative political institutions but at the same time to subject the administrators to strong procedural discipline. Overall, the Kabupatèn Program can be seen not only as a model for other Inpres programs, but also as a significant case study of administrative change in local government in Indonesia.

${ }^{29}$ Interview with T. A. Salim. 